\title{
Bureaucratic champions and unified childcare sectors: neo-liberalism and inclusive liberalism in Atlantic Canadian childcare systems
}

\author{
David McGrane
}

\author{
Correspondence: \\ david.mcgrane@usask.ca \\ Office 206, St. Thomas More \\ College, University of Saskatchewan, \\ 1437 College Drive, Saskatoon, \\ Saskatchewan S7N 0W6, Canada
}

\begin{abstract}
Despite being generally viewed as homogenous, the four provinces that make up Atlantic Canada have quite different Early Childhood Education and Care systems. Through in-depth interviews of policy actors within the four Atlantic Canadian provinces completed in 2011, this article illustrates that Prince Edward Island had an 'inclusive liberal' childcare system. Nova Scotia and New Brunswick mixed elements of 'inclusive liberalism and 'neo-liberalism' in their childcare systems; and Newfoundland had a 'neo-liberal' childcare system. It is argued that the movements towards 'inclusive liberal' childcare systems in Atlantic Canada were engendered through an alliance of bureaucratic champions and unified childcare sectors. Using ideas that linked improved childcare with economic growth, childcare organizations and bureaucratic champions were able to take advantage of opportunities presented by new circumstances in their childcare systems to engender structural reforms.
\end{abstract}

Keywords: Atlantic Canada; Childcare bureaucracy; Inclusive liberalism; Neo-liberalism

Political scientists have generally described Canada's four Atlantic provinces (New Brunswick, Nova Scotia, Prince Edward Island (PEI), and Newfoundland) as relatively homogenous and sharing a similar demographic makeup, history, economy, and political structure (Wiseman 2007; Brownsey and Howlett 2001; Dyck 1995; Bickerton 1990). Yet, a recent report on the Early Childhood Education and Care (ECEC ${ }^{\text {a }}$ ) systems of Canadian provinces illustrates striking divergence within Atlantic Canada (McCain et al. 2011). PEI was found to have one of Canada's most generous and advanced ECEC systems, while Nova Scotia and New Brunswick ranked in the middle of Canadian provinces and Newfoundland ranked last. Indeed, Canada's most prominent national newspaper recently praised PEI for having a 'top-notch childcare system' and launching 'the most comprehensive childcare strategy since Quebec brought in its renowned low-fee program in 1997' (Anderssen, 2013).

This article examines the case of Atlantic Canada to explore the factors that lead towards expansion and retrenchment of ECEC systems. It employs an innovative research design that uses Computer-Assisted Qualitative Data Analysis software (CAQDAS) to code semi-structured interviews with policy actors in Atlantic Canadian ECEC systems. Using a deductive coding scheme known as 'provisional coding', the article illustrates that as of 2011, PEI had decisively moved to an inclusive liberal ECEC model. New Brunswick and Nova Scotia had ECEC systems that mixed elements of 
neo-liberal and inclusive liberal ECEC models, while Newfoundland's ECEC system remained steadfastly neo-liberal.

The following section uses a grounded theory approach that eschews a pre-determined theoretical framework in favor of allowing theory to emerge from the qualitative interview data. Using the inductive methods of initial and focused coding, the article argues that bureaucratic champions co-operating with representatives from relatively unified childcare sectors drove the movement towards inclusive liberal ECEC reforms in Atlantic Canada. These bureaucratic champions and advocates from the childcare sector used ideas that linked ECEC to economic growth to take advantage of opportunities such as the introduction of full-day kindergarten in PEI or the infusion of increased federal childcare funding in the cases of Nova Scotia and New Brunswick. The 'bureaucratic champions and unified childcare sector' theory developed in this case study is congruent with broader public policy literature on 'policy entrepreneurs' as well as research on Canadian ECEC that stresses the role that agency and ideas play in engendering or blocking reform.

\section{Background}

Most of the research on childcare in Canada has concentrated on the ECEC policies of the federal government (Cleveland et al. 2001, 2008; White 2001; Mahon and Phillips 2002; Jenson et al. 2003; Friendly 2000a, 2000b; Friendly and Prentice 2009; McKeen 2009) or comparing Canadian federal government childcare policies to those of other developed countries (Mahon 1999; White 2002a, 2004, 2012; OECD 2004; UNICEF 2008; Turgeon 2010). There has been several interesting case studies that have concentrated on ECEC policies and advocacy within a single province (Lero and Kyle 1991; Hayden 1997; Andrew 1997; Prentice 2000b, 2004; Kershaw 2004, 2005; Martin 2001; Langford 2001, 2011; Tyyska 2001; Friendly 2005; Albanese 2006; Vosko 2006; Jenson 2002, 2009a; Muttart Foundation 2010), two provinces (White 1997; Collier 2001), or Canadian municipalities (Mahon 2005, 2007, 2009b; Prentice 2007; Corter and Pelletier 2010). Though these above studies have concentrated on jurisdictions outside of Atlantic Canada, certain parts of the New Brunswick ECEC system have been examined in comparison with provinces outside of the Atlantic region (Johnson and Mathien 1998; Jenson and Thompson 1999; Langford 2010). However, the only research that systemically compares ECEC in the four Atlantic provinces is Lyon and Canning (2000) that gathered data from 48 childcare centers in 1993 to 1994 and found only minimal differences in quality among the provinces.

These case studies of Canadian childcare have been augmented descriptive and statistical comparisons of the ECEC systems of all ten provinces (Pence 1992; Doherty et al. 2000; Jacobs 2000; Ferguson and Prentice 2000; Prentice 2000a; Bushnik 2006; Human Resources and Social Development Canada 2012). In particular, the Childcare Resource and Research Unit has published ten editions of Early Childhood Education and Care in Canada from 1992 to 2012 that have brought together statistics from a number of sources to create a quantitative portrait of ECEC for each province. One of the most recent studies of this nature is Early Years Study 3 co-authored by McCain et al. (2011). Early Years Study 3 created the 'Early Childhood Education Index' which is a mixture of statistics and basic descriptions to rank the comprehensiveness of the childcare systems of all Canadian provinces on a 15-point scale. Provincial ECEC programs are compared to what the authors identify as an ideal ECEC system where the governance of childcare and 
public education are integrated; standards are enforced to ensure a quality learning environment; and there are high levels of funding, access, and accountability (McCain et al. (2011, p. 101). Confirming previous research, there is a wide variation in provincial scores between a high of '10' for Quebec, a low of '1.5' for Newfoundland, and a provincial average of ' 5.5 .' The divergence among the Atlantic provinces is particularly striking. PEI scored a '9.5', Nova Scotia received a '5', New Brunswick received a '4.5', and Newfoundland scored a '1.5.'

\section{Methods}

At the same time that the statistics for Early Years 3 were being complied, I conducted semi-structured 'face-to-face' interviews with 35 childcare advocates and provincial childcare bureaucrats in Atlantic Canada (see Appendix for details). The interview sample included representatives from provincial government departments that were responsible for 0 - to 5-year-old ECEC, childcare advocacy coalitions, unions that organized childcare workers, and associations representing for-profit childcare center owners, nonprofit childcare centers, and childcare staff. It should be noted that this article concentrates on describing and analyzing the ECEC systems of the Atlantic Canadian provinces in 2011: the time period when the interviews were performed and the Early Years 3 statistics were compiled. As such, one of the limits of the research in this article is that it focuses on the development of Atlantic Canadian childcare systems up to 2011, and it does not take into account developments and reforms that took place after that year.

While Early Years 3 was quite well received in most quarters, there has been some debate in the Canadian ECEC policy community about the strengths and weaknesses of its rating system. The qualitative data in this article provides a means of evaluating the Early Years 3 rating system, at least as it pertains to the four Atlantic Provinces. As will be shown below, the analysis of the qualitative interview data generally confirms the ratings of the Atlantic Provinces contained in Early Years 3. As the interviews were conducted before the release of the Early Years 3, it was not possible to ask participants about their opinions on the ratings system contained in that study.

The result of these interviews was 574 pages of single-spaced interview transcripts. Using NVivo 9, a CAQDAS computer program, the interview transcripts were coded. The first round of coding used a deductive coding process called 'provisional coding' (Saldana 2009, pp. 120-123), where a pre-determined set of codes that corresponded to the elements of the Canadian provincial ECEC systems outlined in Table 1 below was applied to the data. This provisional coding allowed for a comparison of the ECEC systems of the four Atlantic provinces in 2011 and an appreciation of the extent to which the systems conformed to neo-liberal, inclusive liberal, or social democratic ECEC models. Two inductive coding processes were subsequently applied to the data called 'initial coding' and 'focused coding' (Saldana 2009, pp. 81-85, 155-159). As a grounded theory approach to qualitative data analysis, initial coding inductively and spontaneously assigns themes to segments of text. Then, these initial codes are focused into a small number of categories that forms the basis for theory building. Basically, the provisional coding allowed me to answer the research question of how the four childcare systems were different, and the initial/focused coding allowed me to explore the question of why the four childcare systems were different.

The premise of the first round of provisional coding is that the childcare systems of Canadian provinces can be conceived of as a continuum going from neo-liberal to 
Table 1 ECEC models in the Canadian provinces

\begin{tabular}{|c|c|c|}
\hline Neo-liberal & Inclusive liberal & Social democratic \\
\hline $\begin{array}{l}\text { Low spending on ECEC as } \\
\text { percentage of provincial } \\
\text { budget (under 1\%) }\end{array}$ & $\begin{array}{l}\text { Moderate spending on ECEC } \\
\text { as percentage of provincial } \\
\text { budget ( } 1 \% \text { to } 3 \%)\end{array}$ & $\begin{array}{l}\text { High spending on ECEC as } \\
\text { percentage of provincial } \\
\text { budget (over } 3 \%)\end{array}$ \\
\hline $\begin{array}{l}\text { Limited availability of regulated } \\
\text { spaces }\end{array}$ & $\begin{array}{l}\text { Moderate availability of } \\
\text { regulated spaces }\end{array}$ & $\begin{array}{l}\text { High availability of regulated } \\
\text { spaces }\end{array}$ \\
\hline $\begin{array}{l}\text { Encouragement or indifference } \\
\text { to the growth of for-profit } \\
\text { childcare centers }\end{array}$ & $\begin{array}{l}\text { Encouragement of a mix of } \\
\text { for-profit, nonprofit centers, } \\
\text { and public childcare centers }\end{array}$ & $\begin{array}{l}\text { Actively reducing for-profit } \\
\text { childcare centers in favor of } \\
\text { nonprofit childcare centers }\end{array}$ \\
\hline $\begin{array}{l}\text { Voluntary half-day kindergarten } \\
\text { for } 5 \text {-year-olds in public school } \\
\text { system }\end{array}$ & $\begin{array}{l}\text { Mandatory full-day kindergarten } \\
\text { for } 5 \text {-year-olds in public system }\end{array}$ & $\begin{array}{l}\text { Mandatory full-day } \\
\text { pre-kindergarten for all } \\
4 \text {-year-olds and mandatory } \\
\text { full-day kindergarten for all } \\
5 \text {-year-olds in public school } \\
\text { system }\end{array}$ \\
\hline $\begin{array}{l}\text { Heavy reliance on subsidies } \\
\text { targeted to low-income parents } \\
\text { and parents of children with } \\
\text { special needs }\end{array}$ & $\begin{array}{l}\text { Pre-kindergarten programs in } \\
\text { the public school system } \\
\text { targeted to children of } \\
\text { low-income parents }\end{array}$ & $\begin{array}{l}\text { Elimination of all parental } \\
\text { subsidies and provincial } \\
\text { childcare tax credits }\end{array}$ \\
\hline $\begin{array}{l}\text { Provincial tax credits to parents } \\
\text { for childcare expenses }\end{array}$ & $\begin{array}{l}\text { Waning reliance on parental } \\
\text { subsidies and growing use of } \\
\text { operating grants to childcare } \\
\text { centers }\end{array}$ & $\begin{array}{l}\text { One low-cost fee for all } \\
\text { childcare centers (e.g., } \\
\text { US\$7 a day) }\end{array}$ \\
\hline Unregulated parental fees & $\begin{array}{l}\text { Operating grants to centers } \\
\text { to accommodate special } \\
\text { needs children }\end{array}$ & $\begin{array}{l}\text { Salaries of ECEC workers are } \\
\text { comparable to teachers in } \\
\text { elementary and high schools }\end{array}$ \\
\hline $\begin{array}{l}\text { Unregulated childcare worker } \\
\text { wages }\end{array}$ & $\begin{array}{l}\text { No provincial tax credits for } \\
\text { childcare expenses }\end{array}$ & $\begin{array}{l}\text { High legislated standards of } \\
\text { quality }\end{array}$ \\
\hline $\begin{array}{l}\text { Low legislated standards of } \\
\text { quality } \text { for regulated centers }\end{array}$ & Uniform parental fee schedule & $\begin{array}{l}\text { Initiatives to integrate the } \\
\text { care and education of 2- } \\
\text { and 3-year-olds into the } \\
\text { public school system }\end{array}$ \\
\hline \multirow[t]{4}{*}{$\begin{array}{l}\text { Childcare policy placed in } \\
\text { 'social services' department }\end{array}$} & $\begin{array}{l}\text { Mandated salary grid for } \\
\text { childcare workers }\end{array}$ & $\begin{array}{l}\text { Creation of common local } \\
\text { authorities (akin to school } \\
\text { boards) for ECEC for 0- to } \\
\text { 5-year-olds }\end{array}$ \\
\hline & $\begin{array}{l}\text { Moderate legislated standards } \\
\text { of quality including mandating } \\
\text { use of province-wide curriculum } \\
\text { for } 0 \text { - to } 4 \text {-year-olds that links to } \\
\text { the kindergarten curriculum }\end{array}$ & \\
\hline & $\begin{array}{l}\text { Childcare policy pertaining to } \\
0 \text { - to 5-year-olds placed in } \\
\text { 'education' department }\end{array}$ & \\
\hline & $\begin{array}{l}\text { Province-wide use of early } \\
\text { development instrument for } \\
\text { all children prior to, or during, } \\
\text { kindergarten }\end{array}$ & \\
\hline
\end{tabular}

inclusive liberal to social democratic. In a neo-liberal ECEC system, childcare is the private responsibility of parents, and only minimal interference of the state in the childcare market is allowed (Morgan 2003). The provincial government limits its activity to direct financial assistance to parents and minimum quality standards to ensure child safety as well as ensuring that parents are free to choose whatever care arrangement suits their needs. An inclusive liberal ECEC model stresses how governments must make 'social investments' to develop human capital and stresses that the ECEC is 'educational' as opposed to 'care-giving' (Prentice 2004; Mahon 2009a; White 2012). 
The idea of 'social investment' is that governments should make public investments in educating and keeping their populations healthy to ensure a workforce that can compete in the globalized knowledge economy and to reduce future social welfare costs (Jenson 2001, 2009b; White 2012). In terms of childcare, the state should play a large role in regulating, monitoring, building, and expanding the ECEC system to ensure high levels of quality and affordability as well as an overarching focus on children's educational development. Within an inclusive liberal ECEC model, there is a focus on moving children from unregulated private care arrangements to a publicly managed childcare system where there is a mixture of for-profit, non-for-profit, and public auspice. Such 'public management' could include the provincial government, as opposed to the free market, regulating when and where new childcare centers open. A social democratic ECEC model stresses universality and decommodification by providing free or low-cost quality education for all young children and favoring public or nonprofit care over commercial care (Mahon 1999; Bergqvist and Nyberg 2002). The stress is on integrating 0 - to 5-year-old education into the existing school system or regulated nonprofit childcare centers in order to make ECEC as much of a 'public good' as possible. As such, there is a large movement away from unregulated private childcare arrangements into public and nonprofit arrangements.

The precise characteristics of these three ECEC models are outlined in Table 1. It is important to note that no Canadian provincial childcare system will completely conform to one of these ideal types, and a childcare system can simultaneously contain characteristics from all three ideal types. However, the core idea behind this typology is that provinces make linear progress as they shed elements of their neo-liberal ECEC model and embrace elements of the inclusive liberal and social democratic ECEC models. For the most part, a provincial government's ECEC model would follow the broader ideological orientation of the government. For example, one would expect that a right-wing provincial government would hew towards a neo-liberal ECEC model, and a left-wing provincial government would push towards an inclusive liberal or social democratic ECEC model. In fact, a right-wing provincial government could even reverse a previous government's progress towards an inclusive liberal or social democratic ECEC model. However, there may be exceptions to this general rule. A left-wing government concerned about high deficits may only make limited progress in making inclusive liberal or social democratic ECEC reforms. A right-wing government with relatively robust finances may be unwilling to spend the political capital necessary to dismantle inclusive liberal or social democratic ECEC reforms made by previous governments. As such, in every case, the broader political context of the specific province should be taken into account.

\section{Results and Discussion}

The typology outlined in Table 1 relies on both qualitative evaluations and quantitative measurements of Canadian provincial ECEC systems. The qualitative measurements are summarized in Table 2 below. Compared to the other three Atlantic provinces, PEI spent the greatest amount of its total budget on ECEC, had the highest number of regulated spaces relative to its population of 0 - to 5-year-old children, and spent the least on parental subsidies as a percentage of its ECEC spending. In many ways, Newfoundland was the opposite of PEI. When compared to the other three Atlantic 
Table 2 Quantitative measurements of ECEC systems in Canadian provinces (2010 to 2011)

\begin{tabular}{|c|c|c|c|c|c|c|c|c|c|c|}
\hline Quantitative measurement & $\begin{array}{l}\mathrm{NL} \\
(\%)\end{array}$ & $\begin{array}{l}\text { PEI } \\
(\%)\end{array}$ & $\begin{array}{l}\text { NS } \\
(\%)\end{array}$ & $\begin{array}{l}\text { NB } \\
(\%)\end{array}$ & $\begin{array}{l}\text { QC } \\
(\%)\end{array}$ & $\begin{array}{l}\text { ON } \\
(\%)\end{array}$ & $\begin{array}{l}\text { MB } \\
(\%)\end{array}$ & $\begin{array}{l}\text { SK } \\
(\%)\end{array}$ & $\begin{array}{l}A B \\
(\%)\end{array}$ & $\begin{array}{l}\text { BC } \\
(\%)\end{array}$ \\
\hline $\begin{array}{l}\text { Spending on ECEC as a percentage } \\
\text { of the provincial budget }\end{array}$ & 0.62 & 1.71 & 1.39 & 1.29 & 4.70 & 2.01 & 1.50 & 1.36 & 1.13 & 1.36 \\
\hline $\begin{array}{l}\text { Regulated childcare spaces as a } \\
\text { percentage of children } 0 \text { to } \\
5 \text { years old }\end{array}$ & 19 & 42 & 23 & 21 & 29 & 20 & 23 & 11 & 20 & 20 \\
\hline $\begin{array}{l}\text { Percentage of regulated childcare } \\
\text { spaces that are for-profit }\end{array}$ & 72 & 58 & 53 & 62 & 17 & 25 & 5 & 0 & 50 & 43 \\
\hline $\begin{array}{l}\text { Percentage of provincial ECEC } \\
\text { budget spend on parental subsidies }\end{array}$ & 65 & 15 & 47 & 38 & 0 & 46 & 24 & 24 & 63 & 45 \\
\hline
\end{tabular}

Source: McCain et al. (2011) and Friendly et al. (2013).

provinces, it spent the least of its total budget on ECEC, had the fewest regulated spaces relative to its population of 0 - to 5 -year-olds, and spent the largest portion of its ECEC budget on parental subsidies. For their part, Nova Scotia and New Brunswick generally fell somewhere in between PEI and Newfoundland on these quantitative measurements. The only quantitative indicator on which all four of the Atlantic provinces were similar is the percentage of childcare spaces under for-profit auspices (though even here, Newfoundland demarcates itself as having a particularly privatized ECEC system). This finding reflects the well-known fact within the Canadian ECEC policy community that the Atlantic provinces rely on for-profit childcare more than other Canadian provinces.

While undoubtedly useful for basic comparisons, quantitative measurements are insufficient for a truly comprehensive portrait of Atlantic Canadian ECEC systems. The nuanced differences in how these ECEC systems operate can only be captured through the use of interview data. As such, the provisional coding of the interview sample applied 27 pre-determined codes based on Table 1 to the interview data. The provisional coding of the interview dataset generally confirms the findings of Early Years 3 that the four Atlantic provinces had quite divergent ECEC systems. As of 2011, PEI had eliminated many of the elements of its neo-liberal ECEC system to decisively move to an inclusive liberal model. New Brunswick and Nova Scotia had systems that mixed elements of neo-liberalism and inclusive liberalism, while Newfoundland's childcare system remained neo-liberal.

In the time period from 2000 to 2008, the interview sample from PEI described a neo-liberal childcare system where the government played a very minimal role. Private and nonprofit childcare centers were funded by the provincial government to provide half-day kindergarten to 5-year-olds at no cost to parents. Despite a high number of regulated spaces (by Canadian standards), interviewees reported significant problems within the system: fees were unregulated and unaffordable, the wages and educational requirements of childcare workers were low, roughly $60 \%$ of centers were ran as forprofit businesses, operating grants for regulated childcare centers were inadequate, the income eligibility thresholds to quality for subsidies were the lowest in Canadab, parental involvement was not mandated, and the provincial government's standards of quality were minimal.

The provisional coding of the interview sample revealed a veritable childcare revolution in PEI from 2008 to 2011 that transformed the very structure of the ECEC system and 
moved it towards an inclusive liberal model. The reforms are best described as three inter-locking pieces that greatly enhanced the role of the provincial government in funding, managing, expanding, and regulating the childcare system. First, full-day kindergarten, administered by school boards, became mandatory for all 5-year-olds. There were no parental fees for this program, a province-wide curriculum was introduced, and all kindergarten teachers were required to obtain a university level 4-year degree with a concentration in kindergarten.

Second, the provincial government introduced a 'publicly managed' network of Early Years Centers (EYCs). Existing private and nonprofit centers were encouraged to sign contracts to transform themselves into a EYC that had a minimum of 40 children, integrated special needs children, enforced a stricter set of quality standards including higher educational requirements for staff and using a province-wide 0- to 4-year-old curriculum, ensured the functioning of a parental advisory committee, and adhered to a uniform wage grid (with defined benefits) and a standardized fee structure established by the provincial government. The new fee structure kept fees at approximately their same level for most centers, but there will be downward pressure on fees in the future as it is now a political decision by the provincial cabinet every time fees rise. Since these EYCs are not owned or operated by the government, financial statements must be sent to the government and a model of public funding was established to ensure that each EYC makes a minimum of $10 \%$ profit if they operated at $91 \%$ capacity. Over two thirds of PEI's childcare centers took the government's initial offer to become an EYC, and a program was created to buy the licenses of for-profit centers and then add their spaces to the EYC network. Further, the new public funding model meant that EYCs were getting substantially higher operating grants from the government than childcare centers that fall outside of the EYC system whose public funding was capped at US $\$ 15,000$ per year. This difference in funding is meant to encourage centers to come into the EYC system. Under these reforms, the income threshold for when low-income parents become eligible for fully subsidized childcare was raised by US $\$ 2,000$. Nonetheless, due to heavy spending commitments in other areas, the government began to spend much less on parental subsidies as a percentage of their total 0 to 5 childcare/kindergarten budget.

Finally, this new ECEC architecture has necessitated a whole new set of bureaucratic structures and specialized initiatives. The administration of all 0 - to 5-year-old childcare programs was taken out of the Social Services Department and merged to into the Education Department to create the new Department of Education and Early Childhood Development. The PEI Children's Secretariat was created as an advisory group comprised of 12 community and 7 government representatives to provide ongoing monitoring of the new system and suggest improvements. An online centralized waiting list of all EYC childcare spaces in the province was established and a program was created to support curriculum implementation, professional development, and parent engagement in all EYCs. Further, all EYCs are required to participate in data collection projects with the local university to evaluate the effectiveness of the new framework, and all children began undergoing an early development instrument during kindergarten. The government also agreed to pay for the upgrading of the education of staff in EYCs for a period of transition and created a 'career ladder' that is a series of post-secondary programs from entry-level certificates through to Masters and PhDs in ECEC. The scope of these changes required the repealing of the old Childcare Facilities Act and its 
replacement with the Early Learning and Child Care Act in 2010. A crucial part of the new act is that the institution of a supply management model where the provincial government can refuse to license a new private or nonprofit childcare center if it deems that there are sufficient childcare services in the area for which the applicant is applying. In this manner, the provincial government, as opposed to the free market, decides on where and when new centers open.

In 2011, Nova Scotia and New Brunswick had childcare systems that could be characterized as a mix of neo-liberal and inclusive liberal ECEC models. Interviewees pointed to several aspects of the childcare systems in Nova Scotia and New Brunswick that conformed to the neo-liberal model. Both provinces had unregulated parental fees and no regulation around the wages of childcare workers. All childcare grants were available to for-profit and nonprofit centers, and interviewees pointed out that legislated quality standards in Nova Scotia and New Brunswick remained quite minimal.

However, there were also certain elements of the childcare systems in these two provinces that conformed to an inclusive liberal model of ECEC. Both provinces had mandatory full-day kindergarten for 5-year-olds, used an early development instrument during kindergarten, and provided operating grants to childcare centers to accommodate children with special needs. While roughly one third of provincial ECEC funding still went towards parental subsidies, this percentage was dropping as these two provincial governments had decided to eschew tax credits for childcare expenses and to provide more direct funding to regulated centers. As illustrated in Table 1, Nova Scotia and New Brunswick had provincial government spending that was lower, but comparable, to that of PEI and had a moderate availability of regulated childcare spaces for 0 - to 5-year-olds by Canadian standards.

As described above, Early Years 3 found that New Brunswick and Nova Scotia ECEC systems were equally 'advanced' in their movement towards what the authors considered to be an 'ideal' ECEC system. However, provisional coding of the interview sample illustrates that New Brunswick was slightly ahead of Nova Scotia in its progress towards an inclusive liberal model of ECEC. Indeed, New Brunswick's ECEC system included several inclusive liberal elements that Nova Scotia's ECEC system did not. For instance, New Brunswick interviewees pointed out that childcare policy had been moved into the education department and repeatedly mentioned the creation of a new curriculum for 0 - to 4-year-olds that all licensed centers were required to follow. New Brunswick also created the Early Learning and Childcare Trust Fund, an armlength agency with a board appointed by the provincial government, that ensured long-term public funding for regulated space creation, tuition reimbursement for childcare staff upgrading their skills, and the implementation of the 0 - to 4-year-old curriculum. Nine pilot projects, jointly funded by the provincial government and a private philanthropic foundation, had been created in New Brunswick that co-located 0 - to 4-year-old childcare within public schools. Finally, some participants were especially excited about the administration of an 'Early Years Evaluation - Direct Assessment (EYE-DA)' to children 11 months before they entered kindergarten. If the child was found to have developmental weaknesses, a staff person from the school district would intervene to enhance his/her school readiness. The EYE-DA program was in addition to the early development instrument that was administered to children in the second half of kindergarten. Early development instruments assess the aggregate 
development of children in a community, whereas the EYE-DA assesses the development of an individual child.

The provisional coding found that Newfoundland had a very pure neo-liberal ECEC system in 2011. As depicted in Table 1, the provincial government spent only $0.62 \%$ of its budget on ECEC and $65 \%$ of that funding went to parental subsidies. Newfoundland had the second lowest availability of regulated spaces of all Canadian provinces and $72 \%$ of Newfoundland's regulated spaces were under for-profit auspices. Indeed, the provincial government encouraged the growth of the for-profit sector by making virtually all public subsidies available to both for-profit and nonprofit centers. There were no pre-kindergarten programs for 4-year-olds in public schools, and ECEC for 5-year-olds in public schools was limited to voluntary half-day kindergarten. As of 2011, there was no government regulation of childcare worker wages or regulation around parental fees. Childcare policy was placed in the 'social services' department of the provincial government, and several interviewees felt that the quality standards in Newfoundland's regulated centers were the lowest in Atlantic Canada. The only elements of Newfoundland's ECEC system that conformed to an inclusive liberal model were a pilot project to create an early development instrument for children to be administered in the second half of kindergarten and the provision of operating grants directly to centers to accommodate children with special needs.

Newfoundland interviewees outside of government were especially critical of three recent neo-liberal ECEC initiatives by the provincial government that they felt undermined licensed childcare. First, the Education Department was mandated to send out learning resource kits containing books and educational toys to all parents of 0 - to 3-year-old children. Interviewees from outside of the provincial government thought that the funding of such 'gift bags' would be better spent on licensed childcare centers and that such resources were already accessible at public libraries. Second, since expenses from unlicensed childcare arrangements were eligible for a new childcare tax credit contained in the 2011 provincial budget, these interviewees felt that this new tax scheme further encouraged the growth of unlicensed childcare. Finally, the interviewees from outside the government were very negative about the US $\$ 2$ million spent on start-up grants for in-home private childcare arrangements for infants. These interviewees felt that the 30 hour reading course for providers that was required to receive the grants was insufficient to ensure quality care, and the inspections of these new arrangements were too infrequent.

In order to understand why the ECEC systems of the four Atlantic provinces diverged in the manner described above, a round of initial coding was completed which resulted in 52 possible explanations. Using focused coding, these 52 codes were grouped together into three broad explanations for the development of ECEC systems in these provinces. The first explanation was labeled 'agency'. The focused coding revealed that the primary agents affecting the direction of the ECEC policy in these provinces were childcare bureaucrats and the leaders of the associations representing stakeholders within the childcare sector. The interview data that related to agency encompassed descriptions of the specific activities and decisions of these childcare bureaucrats and stakeholders. For example, a childcare bureaucrat can choose to work closely with a certain stakeholder to develop a policy or they 
can develop a policy with little input from that stakeholder. Likewise, a stakeholder group can decide to organize street protests against the provincial government to gain media attention or quietly lobby the provincial government in meetings behind closed doors. In many ways, the 'agency' code boiled down to the choices made by actors within the ECEC systems of these provinces. The second explanation was labeled 'ideas' which explored how childcare was viewed among the participants in the sample and how reforms to the provincial ECEC system were justified. Finally, an explanation emerged that was labeled 'constraints and opportunities' that looked at the constraints imposed on actors by the structural make-up of ECEC in the province and how changes in the dynamics of the system provided opportunities to move away from a neo-liberal ECEC model.

This analysis of the PEI interview sample reveals that the key to understanding the implementation of the EYC system was that agents in the provincial bureaucracy and the childcare sector worked together to take advantage of the opportunity provided by the introduction of full-day kindergarten in 2010. Interviewees pointed out that the newly elected Liberal government moved towards full-day kindergarten because it felt that the province needed to 'catch up' to other provinces that were offering this program and that such a program would help attract and retain skilled workers from other jurisdictions that were needed to grow PEI's economy. However, the government soon realized that moving to full-day kindergarten would create a crisis in the childcare sector because for-profit and nonprofit centers were heavily dependent upon revenue from their half-day kindergarten programs and would be forced to close if these children moved into the public school system.

At this time, slightly over half of childcare centers in PEI were for-profit. However, the vast majority of these for-profit centers were owned by 'owner-operators' who owned a single center and worked alongside their employees on the floor of that center. A private childcare center operators association had formed in 2003 in response to an eventually unsuccessful unionization drive in the province's private childcare centers. However, by 2011, this association had faded away. The result was that PEI's childcare sector was completely united within the Early Childhood Development Association of PEI (ECDA) that acted as a combination of an advocacy organization, an association for directors of nonprofit childcare centers, an association for owners of for-profit centers, and a childcare staff association.

Sensing that the introduction of full-day kindergarten could be an opportunity for systematic change, a group of bureaucratic champions within the provincial government formed a close alliance with the ECDA. The ECDA was the ideal partner for these bureaucratic champions because it was seen as representing the entire childcare sector and it had cultivated bonds of trusts with all of the important players in the sector. In fact, the ECDA built up such a close relationship with the bureaucratic champions that these childcare bureaucrats actually provided free office space for the association within their building.

Through the efforts of the bureaucratic champions and the ECDA, the provincial government was convinced to commission a report on the 0 - to 4-year-old childcare system by Kathleen Flanagan, a retired childcare bureaucrat. The Flanagan report combined ideas of investing in ECEC to create the workers for PEI's future 'knowledge-based economy', integrating early childhood care with education, and the need 
to attract and retain skilled workers to PEI to argue for a complete overhaul of the childcare system for 0- to 4-year-olds along the lines of the EYC centers described in the above section (Flanagan 2010). Flanagan persuasively argued that structural reform of the ECEC system was an important part of the government's 'Island Prosperity' agenda (Government of Prince Edward Island 2007) that sought to use public investments to prepare the province to compete in the global economy, grow its population, and diversify its economy to include a large 'knowledge-based' sector along its traditional industries of agriculture and tourism.

Using Flanagan's ideas, the bureaucratic champions and the ECDA worked in a collaborative fashion to convince the minister responsible for childcare and the rest of the provincial cabinet to approve an extensive set of inclusive liberal ECEC reforms as a 'made-in-PEI' solution to the instability created with the introduction of full-day kindergarten. Reflecting the effectiveness of this lobbying effort, the package of reforms was co-announced by the President of the ECDA, the Minister responsible for childcare, and the Premier. Following the announcement, the ECDA and the bureaucratic champions worked to quickly implement the EYC system to prevent any controversy from arising within the media and minimize instability in the childcare sector. In essence, the movement of PEI's ECEC system to inclusive liberalism is the story of bureaucratic champions in the provincial government being very united with advocates in the childcare sector and using the right ideas at the right time.

Analogous to the PEI case, the creation of the inclusive liberal elements of the New Brunswick ECEC system was driven by agency, opportunity, and ideas. Like PEI, Early Childhood Care and Education New Brunswick (ECCENB) united all of the important players in the province's childcare sector: staff, for-profit operators, nonprofit directors, childcare advocates, and university childcare researchers. The interview sample argued that this relatively unified childcare sector established a good relationship with a number of champions within provincial bureaucracy. In 2005, the federal government signed a Bilateral Agreement-in-Principle on Early Learning and Child Care with each Canadian province ${ }^{\mathrm{c}}$. Flowing from its agreement with Ottawa, a significant infusion of federal cash came into New Brunswick's ECEC system and an important opportunity presented itself. Using the language of social investment and the need to learn from other jurisdictions, the bureaucrats, university researchers, and ECCENB succeeded in convincing the provincial government to use the federal money to put in programs that would have long-term impacts. Most importantly, the government created and implemented a mandatory curriculum for 0- to 4-year-olds in regulated childcare centers. Further, a significant portion of the federal money was placed in a trust fund that could provide stable and ongoing funding for regulated space creation and skills upgrading for childcare staff. A bureaucratic champion was also essential to implementing an Early Years Evaluation tool in the Francophone school system. There was a sense among the interviewees that this movement towards a more inclusive liberal model was solidified when the ECCENB and bureaucratic champions were able to convince the provincial government to follow other jurisdictions and place childcare policy in the education department.

Nonetheless, there were some constraints that prevented New Brunswick from fully moving to an inclusive liberal ECEC model. In terms of ideas, the phrase 'schoolification' was more often mentioned in New Brunswick than in PEI. All interviewees, including 
those advocating for more nonprofit and public provision, were concerned that integrating 0- to 5-year-olds into the school system would create too much regimentation and undermine play-based learning. The phasing out of federal funding from the Bilateral Agreements-in-Principle on Early Learning and Child Care ${ }^{\mathrm{d}}$ following the 2006 election of the Conservative government in Ottawa was also seen as slowing momentum towards new reforms.

The results of the initial and focused coding of the Nova Scotia interview sample revealed substantial differences in terms of agency compared with the PEI and New Brunswick cases. The Nova Scotian interviewees described a fractured childcare sector with a very poor relationship with provincial childcare bureaucrats. The Nova Scotia childcare sector was described as a variety of different organizations representing different interests: a for-profit owners association, a nonprofit directors association, CUPE (the childcare workers' union), a childcare staff association, a childcare advocacy association, and a professional development organization. The interviewees spoke of a considerable tension within the childcare sector among those favoring for-profit childcare, those advocating for public and nonprofit childcare, and those attempting to find a neutral position. This enduring schism within the sector between for-profit and nonprofit was seen as blocking effective lobbying of the provincial government. Interviewees from the childcare sector also felt that provincial childcare bureaucrats rarely consulted with them and did not take their concerns into account when making policy. For their part, the provincial childcare bureaucrats appeared more concerned with consulting directly with parents as opposed to allying with organizations representing the various actors within the childcare sector. In terms of ideas, the phrase 'schoolification' was often mentioned and was used to explain why there was not more integration of the childcare into the school system and why the childcare policy unit had not moved into the education department.

However, like New Brunswick, the interviewees stressed the opportunity provided by the Bilateral Agreement-in-Principle on Early Learning and Child Care in 2005. They argued that many of the inclusive liberal aspects of Nova Scotia's ECEC system such as more regulated space creation, increased funding for childcare centers to accommodate children with special needs, and increased funding for skills upgrading of childcare staff came about as the result of the strategy that the provincial government put into place following the infusion of federal funding in 2005. Nonetheless, there was a sense of pessimism that the ending of that federal funding would prevent future initiatives that would move in an inclusive liberal direction.

The initial and focused coding of the Newfoundland interview sample revealed that agency was an important factor in explaining the province's lack of movement towards an inclusive liberal ECEC model. First, there was a lack of bureaucratic champions pushing forward inclusive liberal ECEC reforms. Rather, the childcare bureaucrats were described as being 'out of touch' with childcare sector and their secretiveness was described as creating a large degree of anxiety and instability within the ECEC system. Interviewees from the childcare sector felt that they were rarely consulted, and when they were consulted, the bureaucrats and provincial government had already decided upon a policy direction. Second, many interviewees stressed the influence of the highly organized private operators association that included many owners of multiple childcare centers who had become 'businesswomen' as opposed to 'owner-operators'. It was claimed that this association was blocking inclusive liberal reforms such as caps on parental fees, a 
uniform salary grid for childcare workers, reduction of government subsidies to for-profit centers, experiments with locating childcare centers in public schools, and higher educational requirements for entry-level childcare workers. Third, participants in the interview sample, including the one from the private operators association, agreed that the provincial government did not take advantage of the federal cash infusion resulting from the Bilateral Agreements-in-Principle on Early Learning and Child Care. Instead of using the new funding for long-term solutions, the provincial government enacted 'band-aid' solutions such as small increases to parental subsidies, wage enhancements, special needs funding, and bursaries for the educational upgrading of childcare staff. Finally, like Nova Scotia and New Brunswick, there was a generalized fear of 'schoolification' that seemed to be preventing the merger of the childcare policy unit into the education department and further integration of the 0 - to 5-year-old ECEC system into the public education system such as moving towards full-day kindergarten for 5 -year-olds in public schools.

\section{Conclusions}

As a grounded theory approach, one of the strengths of initial and focused coding is that it allows the researcher to compare the theory that has arisen from their data to existing theories. The 'bureaucratic champions and unified childcare sector' theory is congruent with the 'policy entrepreneur' literature that emerged from the work of Kingdon (1984). For Kingdon, policy entrepreneurs can be found inside and outside of government and across various policy sectors. Their success depends on a good reputation, good networking skills, and willingness to invest resources (most notably time) in a change process. A general theme running through this literature is that policy entrepreneurs engender systematic change by using the right ideas to exploit a 'window of opportunity' caused by some sort of upheaval. This study of Atlantic Canadian ECEC does bring an innovative element to the policy entrepreneur literature. It suggests that the effectiveness of policy entrepreneurs can be increased when (a) there is an alliance between those working both inside and outside of government and (b) the stakeholders outside of the government are relatively unified. A window of opportunity and the right ideas can only take policy entrepreneurs so far. The case of ECEC in PEI and New Brunswick indicates that the strategic decision to form an alliance of actors inside and outside of government as well as the good fortune of having a united set of stakeholders aids policy entrepreneurs in achieving systematic reform.

The analysis contained in this article also supports the main thrust of research on ECEC reform in Canada that stresses how agency can bring about or block systematic change. For instance, Jenson claims that feminist bureaucrats or 'femocrats' played an important role in the creation of Quebec's US\$5 a day childcare program $(2002,2009 a)$, and Mahon (1999) and Martin (2001) focus on the importance of childcare advocates in pressuring the federal Canadian government to make reforms. However, it is important to note that the bureaucratic champions and childcare advocates in this interview sample were uneasy with the suggestion that they were 'feminists' and their arguments in favor of improving ECEC were generally based on ideas of social investment as opposed to increasing gender equality. For his part, Langford $(2001,2011)$ argues that the influence of private childcare operators worked against the reform of childcare in Alberta. Analogous to Langford's findings, several interviewees in this study clearly pointed to how owners of multiple centers in Newfoundland and Nova Scotia played a role in preventing movement towards 
inclusive liberal reforms such as the creation of more public and nonprofit childcare as well as a uniform fee schedule of parental fees and stricter quality standards. On the other hand, interviewees pointed out how private childcare center operators in PEI and New Brunswick were generally supportive of inclusive liberal reforms in those provinces. It appears that the difference in attitudes among private operators towards the inclusive liberal ECEC model can be attributed to the fact that the private childcare sector in PEI, and to a lesser extent New Brunswick, was dominated by 'owner-operators' who owned only one center. Rather than forming their own lobbying group, these owner-operators were subsumed into the large umbrella group representing the childcare sector and saw inclusive liberal ECEC reforms as positive supports for their center as opposed to a threat.

The role of ideas such as nationalism in Quebec or discourses on social investment have been found to be important in pushing more generous ECEC policies in Canada (White 2001, 2002a, 2004, 2011a, 2011b; Béland and Lecours 2006, 2008; Mahon 2011). In this case study, ideas emerged as particularly important. Ideas of social investment, linking ECEC to the government's economic growth agenda, and learning from the 'best practices' of other jurisdictions were influential in pushing towards an inclusive liberal model. However, it is imprudent to subscribe too much explanatory power to the presence of ideas around social investment. Similar to White's recent finding (2012) that the adoption of a social investment paradigm does not necessarily mean movement away from neoliberal models of ECEC, this study found that social investment ideas were prevalent in all provinces examined, including those with more neo-liberal elements in their models. By 2011, social investment had become a common language and accepted paradigm among ECEC policy actors in Atlantic Canada. In and of themselves, social investment ideas were not able to secure inclusive liberal reforms. Rather, ideas of social investment had to combine with other factors such as the presence of bureaucratic champions, a unified childcare sector, and appropriate opportunities for systematic change to push inclusive liberal reform.

For the most part, the stress in the literature on Canadian ECEC has been on the ideas that push for more generous policies. The initial and focused coding of the Atlantic Canadian interview sample revealed ideas that appeared to be acting as a bulwark against the implementation of an inclusive liberal ECEC model. As noted above, fears about 'schoolification' was a reason given for not adopting key components of the inclusive liberal model such as pre-kindergarten for 4-year-olds and moving childcare policy into the provincial education department. Likewise, in Nova Scotia and Newfoundland, there was a strong discourse around allowing parents to 'choose' between private and nonprofit childcare within the interview sample. Similar to Kershaw's work on ECEC in British Columbia (2004), this discourse around parental choice was found to work against the encouragement of more nonprofit and public childcare that is part of the inclusive liberal model.

This case study of Atlantic Canadian ECEC is generally unsupportive of research that points to the institutional framework of Canadian federalism as being a barrier against reform in an inclusive liberal direction (Bach and Phillips 1998; Friendly 2001a, 2001b; White 2002b; Prentice 2006; Friendly and White 2008; White 2011b). Despite each Atlantic Canadian province receiving ostensibly similar increases to federal funding in 2005 coming out of the Bilateral Agreements-in-Principle on Early Learning and Child Care, the outcomes diverged greatly. In the case of PEI, the action of the federal government on the childcare file was superfluous to the establishment of the EYC system. The interview sample described how the Bilateral Agreements had resulted in 
only small improvements to ECEC in PEI. Rather, the implementation of an EYC system was driven by factors that were internal to PEI and took place after the federal funding from the Bilateral Agreements had been eliminated. In the case of Newfoundland, the Bilateral Agreements were not seen as pushing the ECEC system away from a neoliberal model and in an inclusive liberal direction. However, in New Brunswick, and to a lesser extent Nova Scotia, the Bilateral Agreements actually provided stimulus to inclusive liberal reforms. An external stimulus from Ottawa represented an opportunity to move towards inclusive liberalism in these two provinces. On the other hand, the cancelling of funding from the Bilateral Agreements was also seen as halting the momentum towards further inclusive liberal ECEC reform in New Brunswick and Nova Scotia.

The case of the Bilateral Agreements-in-Principle on Early Learning and Child Care and Atlantic Canada points to the possibility that the impact of federalism can vary by case and time period. At times, action by the federal government can push forward ECEC reform. At other times, activity by the federal government can hold back ECEC forms. Still, in other instances, ECEC reform can leap forward or stagnate because of factors completely independent of the federal government. As such, this case study supports recent research by Mahon and Brennan that argues that impact of institutional configuration of federalism on Canadian and Australian ECEC systems is 'not definitive' but interacts with a number of variables to explain policy design (2013).

Finally, certain explanations of the evolution of ECEC policies in Canada are simply not well supported by this case study of Atlantic Canada. In other studies, factors pushing towards more generous ECEC policies include high fertility rates and women's labor market participation (Henderson and White 2004; O'Neill 2006), the strength of feminist groups (Timpson 2001; Langford 2001; Martin 2001; Mahon 1999; Jenson 2002, 2009a), and the election of left-of-center governing parties or strong unions in the childcare sector (White 1997; Collier 2001; Kershaw 2004). However, none of these factors were found to be influential within the initial and focused coding of the interview sample.

Overall, the case study of Atlantic Canadian childcare highlights important lessons for policy actors desiring to push away from a neo-liberal model of ECEC to an inclusive liberal model. Perhaps because their children are not in the ECEC system for a long period of time, parents are quite passive in terms of creating reform in the childcare sector. In Atlantic Canada, parental pressure was very infrequently mentioned as a reason for reform in the childcare sector, and the parents of children in Atlantic Canadian ECEC systems were not even organized into an association or any coherent manner. Similarly, political parties or ministers were not seen as major forces of innovation or reform. Rather, those directly working within ECEC such as childcare bureaucrats and leaders of organizations representing the childcare sector drove reform. These policy entrepreneurs succeeded when there was a united childcare sector that was able to speak to the provincial government with a single voice, an alliance of those working inside and outside of government, ideas connecting ECEC reforms to increasing economic growth, and opportunities in the form of upheaval in the childcare sector or activity of external actors like the federal government.

\section{Endnotes}

atWhile some Canadian researchers have argued for a broad definition of ECEC that includes care and education for children 0 to 12 years old, I will use a narrow definition of ECEC as nonparental care and education for children under the age of six. 
${ }^{\mathrm{b}}$ This observation, made by a number of interviewees, can be verified on page 208 of Beach et al. (2009).

'Under the leadership of Ken Dryden, the federal social development minister, the Canadian federal government signed bilateral agreements on childcare with each Canadian province between April and November 2005. As a whole, the agreements committed to a US $\$ 5$ billion transfer of money from Ottawa to provincial governments over 5 years to build ECEC programs based on the 'QUAD' principles: quality, universality, accessibility, and developmentally focused programming; see Friendly and White (2008).

${ }^{\mathrm{d}}$ Details on changes made in direct federal transfers to provinces for ECEC from 2000 to 2010 can be found on pages 24 to 25 of Human Resources and Social Development Canada (2012).

${ }^{\mathrm{e} S t a n d a r d s}$ of quality would include staff-to-children ratios, educational requirements of staff, space requirements, nutritional requirements, professional development opportunities for staff, parental involvement, inspections, penalties for noncompliance, and online registry of all licensed childcare providers.

\section{Appendix}

All interviews for this article were completed in person during the time period from 26 May to 10 June 2011. A 'snowball' interview sampling technique was used where a key informant for each province was chosen who referred the interviewer to participants for the study. The interviews were recorded and transcribed before being analyzed using NVivo 9. The provincial government officials overseeing kindergarten in Newfoundland's education department did consent to a recorded interview. However, officials from the Newfoundland's childcare policy unit refused to have their interview recorded. Instead, an official from that unit provided written answers to my questions. Below is a list of all interviewees for this project. They all signed consent forms, giving permissions for their names and positions to be published:

PEI

Sonya Corrigan, Executive Director, Early Childhood Development Association of PEI Martha Gabriel, Associate Professor, Faculty of Education, University of PEI

Ray Doiron, Professor, Faculty of Education, University of PEI

Carolyn Simpson, Early Childhood Development and Kindergarten Manager, Department of Learning and Early Childhood Development

Cathy McCormack, Early Childhood Programs Administrator, Department of Learning and Early Childhood Development

Lynn Arnseault, Owner and Director, Bright Futures Development Center

Kathleen Flanagan, Child and Family Policy Consultant, Kathleen Flanagan and Associates

Bob Creed, Director, Social Programs and Housing, Department of Community Services, Seniors, and Labour

Jason MacDonald, Supervisor of Daycare Subsidies, Department of Community Services, Seniors, and Labour

Ann Robertson, Executive Director, CHANCES Family Centre

Doreen Baird, Early Years Coordinator for SmartStart Programs, CHANCES Family Centre 


\section{New Brunswick}

Jody Carr, Minister, Department of Education and Early Childhood Development

Marjolaine St. Pierre, Executive Director, Early Childhood Care and Education New Brunswick

Jennifer Arsneault, Owner and Operator, Saint John Early Childhood Center

Robert Laurie, Director of Assessment and Evaluation Branch, Department of Education and Early Childhood Development

Pam Whitty, Director of the Early Childhood Centre, University of New Brunswick

Nicole Gervais, Executive Director of Early Childhood Development, Department of Education and Early Childhood Development

Diane Lutes, Acting Director, Early Learning and Childcare, Department of Education and Early Childhood Development

Gina St. Laurent, Director of Student Services, Department of Education and Early Childhood Development

Nova Scotia

Elaine Ferguson, Executive Director, Child Care Connections NS

Virginia O'Connell, Director of Early Childhood Development Services, Department of Community Services

Shelley Thompson, Co-ordinator of Childcare Centre Policy and Program Development, Department of Community Services

Jerry MacKinlay, Coordinator of the Nova Scotia Child Subsides Program, Department of Community Services

Nicholas Phillips, Coordinator of Special Needs Policy Program Development, Department of Community Services

Karen Wright, President of CUPE 4757 and President of the Nova Scotia Childcare Advocacy Association

Karen Geddes, Co-Chair, Non-Profit Directors Association of Nova Scotia

Heather Hansen-Dunbar, Chairperson, Private Licensed Administrators Association of Nova Scotia (P.L.A.Y)

Kathleen Couture, Chairperson, Nova Scotia Childcare Association

Nancy Taylor, Early Learning Coordinator, Department of Education

Newfoundland

Mary Walsh, Chairperson, Association of Early Childhood Educators of Newfoundland and Labrador

Lorraine Michaels, Leader, Newfoundland and Labrador NDP

Joanne Morris, Board Member, Coalition for Quality Childcare of Newfoundland and Labrador

Brian Farewell, National Representative and Childcare Coordinator, CUPE Newfoundland and Labrador

Paula Hennessey, Director of Early Childhood Learning Division, Department of Education

Rosalyn Bennett, President, Provincial Association of Childcare Administrators and Licentiate of Newfoundland and Labrador

Christine McLean, Program Consultant, Child Care Services, Department of Child, Youth and Family Services (written response) 


\section{Competing interests}

The author declares that he has no competing interests.

\section{Acknowledgements}

The author would like to thank Sarah Shoker and Peter Bruce for their excellent research assistance and also express his gratitude to St. Thomas More College for its funding of this project. This article was significantly strengthened by the comments of three anonymous reviewers, and the author would like to thank them for their diligent and thoughtful analysis.

\section{Received: 7 November 2013 Accepted: 21 April 2014}

\section{Published online: 08 October 2014}

\section{References}

Albanese, P. (2006). Small town, big benefits: the ripple effect of $\$ 7 /$ day child care. Canadian Review of Sociology and Anthropology, 43(2), 125-140

Anderssen, E. (2013). What PEI and Quebec can teach the rest of Canada about improving child care. Globe and Mail, October 25, A8.

Andrew, C. (1997). Le gouvernement Harris et la garde des enfants: la privatisation, la municipalisation, ou autre chose? In R Dandurand, P Lefebvre, \& JP Lamoureux (Eds.), Quelle politique familiale à l'aube de l'an 2000? L'Harmattan: Montreal.

Bach, S, \& Phillips, S. (1998). Constituting a new social union: Child care beyond infancy? In G Swimmer (Ed.), How Ottawa spends, 1997-98: Seeing red: A liberal report card. Ottawa: Carleton University Press.

Beach, J, Friendly, M, Ferns, C, Prabhu, N, \& Forer, B. (2009). Early Childhood Education and Care in Canada 2008 (8th ed.) Toronto: Childcare Resource and Research Unit.

Béland, D, \& Lecours, A. (2006). Sub-state nationalism and the welfare state: Quebec and Canadian federalism. Nations and Nationalism, 12(1), 77-96.

Béland, D, \& Lecours, A. (2008). Nationalism and social policy: The politics of territorial solidarity. Oxford: Oxford University Press. Bergqvist, C, \& Nyberg, A. (2002). Welfare state restructuring and child care in Sweden. In S Michel \& R Mahon (Eds.), Child care policy at the crossroads: Gender and welfare state restructuring. London: Routledge.

Bickerton, J. (1990). Creating Atlantic Canada. In A Gagnon \& J Bickerton (Eds.), Canadian politics: An introduction to the discipline. Peterborough: Broadview Press.

Brownsey, K, \& Howlett, M (Eds.). (2001). The provincial state in Canada: Politics in the provinces and territories. Peterborough: Broadview Press.

Bushnik, T. (2006). Child care in Canada. Ottawa: Statistics Canada.

Cleveland, G, \& Krashinsky, M (Eds.). (2001). Our children's future: Child care policy in Canada. Toronto: University of Toronto Press.

Cleveland, G, Forer, B, Hyatt, D, Japel, C, \& Krashinsky, M. (2008). New evidence about childcare in Canada: Use patterns, affordability and quality. Montreal: Institute for Research on Public Policy.

Collier, C. (2001). Working with parties: Success and failure of child care advocates in British Columbia and Ontario in the 1990s. In S Prentice (Ed.), Changing child care: Five decades of child care advocacy and policy in Canada. Halifax: Fernwood Publishing.

Corter, C, \& Pelletier, J. (2010). Schools as integrated service hubs for young children and families: Policy implications of the Toronto First Duty Project. International Journal of Child Care and Education Policy, 4(2), 45-54.

Doherty, G, LaGrange, A, Lero, D, Tougas, J, \& Goelman, H. (2000). You bet I care!: A Canada-wide study on wages, working conditions, and practices in child care centres. Guelph: Centre for Families, Work \& Well-Being.

Dyck, R. (1995). Provincial politics in Canada: Towards the turn of the century (3rd ed.). Scarborough: Prentice Hall Canada.

Ferguson, E, \& Prentice, S. (2000). Exploring parental involvement in Canada: An ideological maze. In J Hayen (Ed.), Landscapes in early childhood education: Cross national perspectives on empowerment, a guide for the new millennium. New York: Peter Lang Publishing.

Friendly, M, \& Prentice, S. (2009). About Canada: Childcare. Halifax: Fernwood Publishing

Friendly, M, \& White, L. (2008). From multilateralism to bilateralism to unilateralism in three short years: Child care in Canadian federalism. In H Bakvis \& G Skogstad (Eds.), Canadian federalism: Performance, effectiveness, and legitimacy (2nd ed.). Don Mills: Oxford University Press.

Friendly, M, Halfon, S, Beach, J, \& Forer, B. (2013). Early Childhood Education and Care in Canada 2012 (9th ed.). Toronto: Childcare Resource and Research Unit.

Friendly, M. (2000a). Early childhood education on the Canadian policy landscape. In J Hayden (Ed.), Landscapes in early childhood education: Cross national perspectives on empowerment, a guide for the new millennium. New York: Peter Lang Publishing.

Friendly, M. (2000b). Child care as a social policy issue. In L Prochner \& N Howe (Eds.), Early childhood care and education in Canada. Vancouver: University of British Columbia Press.

Friendly, M. (2001a). Is this as good as it gets? Child care as a test case for assessing the Social Union Framework Agreement. Canadian Review of Social Policy, 47, 77-82.

Friendly, M. (2001b). Child care and Canadian federalism in the 1990s: Canary in a coal mine. In G Cleveland \& M Krashinsky (Eds.), Our children's future: Child care policy in Canada. Toronto: University of Toronto Press.

Friendly, M. (2005). Early learning and child care in Saskatchewan: Past, present and future, Public Policy Paper No. 36. Regina: Saskatchewan Institute of Public Policy.

Flanagan, K. (2010). The early years report, early learning in PEl: An investment in the island's future. Charlottetown: Department of Education and Early Childhood Development, Government of Prince Edward Island.

Government of Prince Edward Island. (2007). Island prosperity: A focus for change. Charlottetown: Government of Prince Edward Island. 
Hayden, J. (1997). Neo-conservatism and child care services in Alberta: A case study, Occasional Paper No. 9. Toronto: Childcare Resource and Research Unit.

Henderson, A, \& White, L. (2004). Shrinking welfare states? Comparing maternity leave benefits and child care programs in European Union and North American Welfare States, 1985-2000. Journal of European Public Policy, 11(3), 497-519.

Human Resources and Social Development Canada. (2012). Public investments in early childhood education in Canada 2010. Ottawa: Human Resources and Social Development Canada.

Jacobs, E. (2000). A national picture of child care options. In N Howe \& L Prochner (Eds.), Early childhood care and education in Canada. Vancouver: University of British Columbia Press.

Jenson, J, \& Thompson, S. (1999). Comparative family policy: Six provincial stories. Ottawa: Canadian Research Policy Networks.

Jenson, J, Mahon, R, \& Phillips, S. (2003). No minor matter: The political economy of childcare in Canada. In W Clement \& L Vosko (Eds.), Changing Canada: Political economy as transformation. Montreal: McGill-Queen's University Press.

Jenson, J. (2001). Canada's shifting citizenship regime: Investing in children. In T Salmon \& M Keating (Eds.), The dynamics of decentralization: Canadian federalism and British devolution. Montreal: McGill-Queen's University Press.

Jenson, J. (2002). Against the current: Child care and family policy in Quebec. In S Michel \& R Mahon (Eds.), Child care policy at the crossroad: Gender and welfare state restructuring. London: Routledge.

Jenson, J. (2009a). Rolling out or backtracking on Quebec's childcare system? In M Griffin Cohen \& J Pulkingham (Eds.) Public policy for women: The state, income security, and labour market issues. Toronto: University of Toronto Press.

Jenson, J. (2009b). Writing gender out: The continuing effects of the social investment perspective. In A Dobrowolsky (Ed.), Women and public policy in Canada: Neoliberalism and after? Oxford: Oxford University Press.

Johnson, L, \& Mathien, J. (1998). Early childhood services for kindergarten-age children in four Canadian provinces: Scope, nature and models for the future. Ottawa: Caledon Institute of Social Policy.

Kershaw, P. (2004). 'Choice' discourse in BC child care: Distancing policy from research. Canadian Journal of Political Sciences, 37(4), 927-950.

Kershaw, P. (2005). Carefair: Rethinking the responsibilities and rights of citizenship. Vancouver: University of British Columbia Press.

Kingdon, JW. (1984). Agendas, alternatives and public policies. New York: Harper Collins.

Langford, R. (2010). Innovations in provincial early learning curriculum frameworks. Toronto: Childcare Resource and Research Unit.

Langford, T. (2001). From social movements to marginalized groups: Advocating for quality child care in Alberta, 1965-86. In S Prentice (Ed.), Changing child care: Five decades of child care advocacy and policy in Canada. Halifax: Fernwood Publishing.

Langford, T. (2011). Alberta's day care controversy: From 1908 to 2009 and beyond. Edmonton: Athabasca University Press.

Lero, D, \& Kyle, I. (1991). Work, families and child care in Ontario. In L Johnson \& D Barnhorst (Eds.), Children, families and public policy in the 90s. Toronto: Thompson Educational Publishing.

Lyon, M, \& Canning, P. (2000). The social policy context of daycare in four Canadian provinces. In J Hayden (Ed.), Landscapes in early childhood education: Cross national perspectives on empowerment, a guide for the new millennium. New York: Peter Lang Publishing.

Mahon, R, \& Phillips, S. (2002). Dual-earner families caught in a liberal welfare regime? The politics of child care policy in Canada. In S Michel \& R Mahon (Eds.), Child care policy at the crossroad: Gender and welfare state restructuring. London: Routledge.

Mahon, R, \& Brennan, D. (2013). Federalism and the "New Politics" of welfare development: Childcare and parental leave in Australia and Canada. Publius, 43(1), 90-108.

Mahon, R. (1999). 'Both wage earner and mother': Women's organizing and childcare policy in Sweden and Canada. In L Briskin \& M Eliasson (Eds.), Women's organizing and public policy in Canada and Sweden. Montreal: McGill-Queen's University Press.

Mahon, R. (2005). Rescaling social reproduction: Childcare in Toronto/Canada and Stockholm/Sweden. International Journal of Urban and Regional Research, 29(2), 341-357.

Mahon, R. (2007). Challenging national regimes from below: Toronto child care politics. Politics and Gender, 3(1), 55-78.

Mahon, R. (2009a). Child care and varieties of liberalism in Canada. In A Dobrowolsky (Ed.), Women and public policy in Canada: Neoliberalism and after? Oxford: Oxford University Press.

Mahon, R. (2009b). Of scalar hierarchies and welfare redesign: Child care in four Canadian cities. In R Keil \& R Mahon (Eds.), Leviathan undone? Towards a political economy of scale. Vancouver: UBC Press.

Mahon, R. (2011). Transnationalizing (child) care policy: The OECD and the World Bank. In R Mahon \& F Robinson (Eds.), Feminist ethics and social policy: Towards a new global political economy of care. Vancouver: UBC Press.

Martin, J. (2001). History, lessons, and a case for change in child care advocacy. In S Prentice (Ed.), Changing child care: Five decades of child care advocacy and policy in Canada. Halifax: Fernwood Publishing.

Morgan, K. (2003). Child care and the liberal welfare regime: A review essay. Review of Policy Research, 20(4), 743-748.

McCain, M, Mustard, F, \& McCuaig, K. (2011). Early years study 3: Making decisions, taking action. Toronto: Margaret and Wallace McCain Family Foundation.

McKeen, W. (2009). The politics of the National Children's Agenda: A critical analysis of contemporary neoliberal social policy change. In M Griffin Cohen \& J Pulkingham (Eds.), Public policy for women: The state, income security, and labour market issues. Toronto: University of Toronto Press.

Foundation, M. (2010). In the best interests of children and families: A discussion of Early Childhood Education and Care in Alberta. Edmonton: The Muttart Foundation.

O'Neill, B. (2006). Women's status across the Canadian provinces, 1999-2002: Exploring differences and possible explanations. In C Dunn (Ed.), Provinces: Canadian provincial politics (2nd ed.). Peterborough: Broadview Press.

Organization for Economic Co-operation and Development (OECD). (2004). Canada country note. Paris: Directorate for Education, OECD.

Pence, A. (1992). Canadian national child care study: Canadian child care in context: Perspectives from the provinces and territories. Ottawa: Statistics Canada. 
Prentice, S. (2000a). The business of child care: The issue of auspice. In L Prochner \& N Howe (Eds.), Early childhood care and education in Canada. Vancouver: University of British Columbia Press.

Prentice, S. (2000b). A decade of decline: Regulated child care in Manitoba, 1989-1999. Ottawa: Canadian Centre for Policy Alternatives.

Prentice, S. (2004). Manitoba's childcare regime: Social liberalism in flux. Canadian Journal of Sociology, 29(2), 193-207.

Prentice, S. (2006). Childcare co-production and the third sector in Canada. Public Management Review, 8(4), 521-536.

Prentice, S. (2007). Childcare, justice and the city: A case study of planning failure in Winnipeg. Canadian Journal of Urban Research, 16(1), 92-108.

Turgeon, L. (2010). Tax, time and territory: The development of early childhood education and childcare in Canada and Great Britain. Toronto: Unpublished Dissertation, Department of Political Science, University of Toronto.

Saldana, J. (2009). The coding manual for qualitative researchers. London: Sage Publications.

Timpson, A. (2001). Driven apart: Women's employment equality and child care in Canadian public policy. Vancouver: UBC Press.

Tyyska, V. (2001). Child care policy in Ontario in the 1990s. In S Prentice (Ed.), Changing child care: Five decades of child care advocacy and policy in Canada. Halifax: Fernwood Publishing.

United Nations Children's Fund (UNICEF). (2008). The childcare transition, Innocenti Report Card 8. Florence: UNICEF Innocenti Research Centre.

Vosko, L. (2006). Crisis tendencies in social reproduction: The case of Ontario's Early Years plan. In K Bezanson \& M Luxton (Eds.), Social reproduction: Feminist political economy challenges neo-liberalism. Montreal: McGill-Queen's University Press.

White, L. (1997). Partisanship or politics of austerity? Child care policy development in Ontario and Alberta, 1980 to 1996. Journal of Family Issues, 18(1), 7-29.

White, L. (2001). From ideal to pragmatic politics: national child care advocacy groups in the 1980s and 1990s. In S Prentice (Ed.), Changing child care: Five decades of childcare advocacy and policy in Canada. Halifax: Fernwood Publishing.

White, L. (2002a). Ideas and the welfare state explaining child care policy development in Canada and the United States. Comparative Political Studies, 35(6), 713-743.

White, L. (2002b). The child care agenda and the social union. In H Bakvis \& G Skogstad (Eds.), Canadian federalism: Performance, effectiveness, and legitimacy. Toronto: Oxford University Press.

White, L. (2004). Trends in child care/early childhood education/early childhood development policy in Canada and the United States. The American Review of Canadian Studies, 34(4), 665-687.

White, L. (2011a). The internationalization of Early Childhood Education and Care (ECEC) issues: Framing gender justice and child well-being. An International Journal of Policy, Administration and Institutions, 24(2), 285-309.

White, L. (2011b). Institutional 'stickiness' and ideational resistance to paradigm change: Canada and Early Childhood Education and Care (ECEC) policy. In G Skogstad (Ed.), Policy paradigms, transnationalism, and domestic politics. Toronto: University of Toronto Press.

White, L. (2012). Must we all be paradigmatic? Social investment policies and liberal welfare states. Canadian Journal of Political Science, 45(3), 657-683.

Wiseman, N. (2007). In search of Canadian political culture. Vancouver: UBC Press.

doi:10.1007/s40723-014-0001-8

Cite this article as: McGrane: Bureaucratic champions and unified childcare sectors: neo-liberalism and inclusive liberalism in Atlantic Canadian childcare systems. International Journal of Child Care and Education Policy 2014 8:1.

\section{Submit your manuscript to a SpringerOpen ${ }^{\circ}$ journal and benefit from:}

- Convenient online submission

- Rigorous peer review

- Immediate publication on acceptance

- Open access: articles freely available online

- High visibility within the field

- Retaining the copyright to your article

Submit your next manuscript at $\gg$ springeropen.com 